\title{
5
}

\section{Recycling Patriarchy's Garbage: George Eliot's Pessimism and the Problem of a Site for Feminism}

Theorists have long considered the way Western metaphysics has formed around metaphors of sight. Our notions of reality are informed by our understanding of what the visual means, especially by the assumption that the observation of empirical data somehow offers access to universal truth and natural law. So too literature and literary theory have always been intrigued by the relations between the linguistic and the visual. The conventions of literary realism rely on verbal imitations of such supposedly objective observation, proceeding as if a thousand words can actually equal a picture. Recent post-structural literary theory and criticism have investigated in particular this privileging of sight and the way language attempts to lay claim to it. One feminist approach, influenced especially by Lacanian psychoanalysis, foregrounds the importance of gender in its unraveling of the epistemological assumptions implied in questions of representation. By focusing on what critical shorthand terms "the male gaze," these feminists have demonstrated how the scapegoating of women within the specular economy mars its transparency and brings its assumptions to our attention. ${ }^{1}$ But more recent-Foucauldian-approaches to the stra-

\footnotetext{
'See, for example, Laura Mulvey, "Visual Pleasure and the Narrative Cinema," Screen 16 (1975): 6-18, and her "Afterthoughts on Visual Pleasure and the Narrative Cinema Inspired by 'Duel in the Sun'," Framework 15/16 (1981): 12-15. See also E. Ann Kaplan, "Is the Gaze Male?" in Powers of Desire: The Politics of Sexuality, ed. Ann Snitow, Christine Stansell, and Sharon Thompson (1983), 309-27. See also such critiques or revisions of the concept of the male gaze as Miriam Hansen, "Pleasure, Ambivalence, Identification: Valentino and Female Spectatorship," Cinema Journal 25
} 
tegic use of metaphors of sight have dispensed with the focus on gender, implying that gender divisions into oppressed and oppressor can be simply another attempt to imagine autonomy and escape from a generalized power that locates its supervision in its totalizing field of vision and oversees through its indifferent seeing. ${ }^{2}$

Through an attention to genre, I want to consider in this chapter just how the category of woman might be related to linguistic gestures to the visual. Why, in this debate, is gender division sometimes foregrounded, sometimes ignored? I approach these questions by considering the role of detail in the visual metaphors with which George Eliot distinguishes between realism and romance in her novels. Her works-about the intractability of our social relations, the powerlessness of human will-lead to the same crux that critical theory (especially for those of us working in feminist theory) seems halted at right now: how to think our way out of the very assumptions and constraints determining our thought, how to provide alternatives that aren't just more of the same "narrow, ugly, grovelling existence" that Eliot often paints as the real picture of human life. ${ }^{3}$ Eliot's works continually illustrate

(Summer 1986): 6-57; Mary Ann Doane, The Desire to Desire: The Woman's Film of the 1940s (1987); and Kaja Silverman, The Acoustic Mirror: The Female Voice in Psychoanalysis and Cinema (1988).

${ }^{2}$ For discussions of the use of surveillance in literature, which dispense with or critique traditional assumptions about the role of gender division within the specular, see Mark Seltzer, Henry James and the Art of Power (1984), 25-58; and D. A. Miller, The Novel and the Police (1988), especially 169-72.

${ }^{3}$ George Eliot, The Mill on the Floss, ed. A. S. Byatt (1979), bk. 4, ch. 1, p. 362; all future references to this book (hereafter abbreviated $M F$ ) will appear in the text. This particular phrase comes from a well-known passage in which Eliot directly contrasts romance and realism. She compares the romance of Rhenish castles to the "dismal remnants of commonplace houses . . . the sign of a sordid life" (MF.4.1.361) on the Rhone: "Therefore it is that these Rhine castles thrill me with a sense of poetry: they belong to the grand historic life of humanity, and raise up for me the vision of an epoch. But these dead-tinted, hollow-eyed, angular skeletons of villages on the Rhone, oppress me with the feeling that human life-very much of it-is a narrow, ugly, grovelling existence, which even calamity does not elevate, but rather tends to exhibit in all its bare vulgarity of conception; and I have a cruel conviction that the lives these ruins are the traces of were part of a gross sum of obscure vitality, that will be swept into the same oblivion with the generations of ants and beavers" (4.1.362). This passage reveals how the connections between realism and romance are associated with the language of the specular as well as with our inability as subjects to elude the specular, the way the choice between sight/lack of sight remains a paradox: realism, for example, here exhibits only "traces" that tend toward oblivion. 
that the alternative-romance, for instance, instead of the realism it counters-is not really different from the original problem. The very structures that teach us to think, theorize, speculate, are (by the persistence of visual metaphors that gives us terms like "speculate") constructed so as to control our resistance to them as well. What intrigues Eliot (sometimes, it seems, despite herself)-and intrigues me about her-is the way that gender division operates as the vehicle of such speculation and supposed resistance. Her novels consider the paralysis produced by a recognition of our always coopted contingency (think of all the paralyzed characters in her stories, from Silas Marner to Mr. Tulliver); they consider too how the cause of such paralysis is scapegoated onto women (Hetty, Maggie, even Dorothea, are all cast as Medusae) - and how it devastates them.

Gender is important in a breakdown of the distinction between realism and romance in Eliot's fiction, and its importance turns on the duplicity of detail. Realism directly opposes itself to that alternative mode of presentation, romance, by claiming a special relation to visual data and privileging those data as the real. Realism supposedly presents an objective picture that displays common, everyday details in their proper light; romance sees either too much or too little, charting some illusory realm outside the ordinary. Yet, as Naomi Schor argues, any focus on ordinary or extraordinary detail relies on gender assumptions. "The detail is gendered and doubly gendered as feminine," she writes; it is "bounded on the one side by the ornamental, with its traditional connotations of effeminacy and decadence, and on the other, by the everyday, whose 'prosiness' is rooted in the domestic sphere of social life presided over by women." 4 This gendering of detail as feminine is so insistent that the association of women and detail persists even in aspects of detail-the decadent, the everyday-that seem contradictory.

In this chapter, I want to elaborate the contradictions implied in the relations between women and detail that Schor's study notes. A focus on detail reveals the double bind constraining the category of woman in literary realism and current critical debate (Schor also notes a "rare prominence" of detail in post-structural theory). ${ }^{5}$ It is

4Naomi Schor, Reading in Detail: Aesthetics and the Feminine (1987), 4.

5Schor, Reading in Detail, 3. Schor's study isolates the importance of detail within the theories of writers such as Barthes, Derrida, and Foucault: "The ongoing val- 
not just that woman cannot escape her association with detail, however paradoxical, but that that association reveals something about her position in the signifying system. Just as she is associated with a doubleness of detail (details so overly elaborate as to force our attention to them, so common as to be almost invisible), she is at the same time doubly related to the specular system (implicated within, if not made the very site for, it, she is also aligned with attempts to escape that system). Such contradictions, though common to all subjects, are scapegoated onto women. The devaluing of women implied in the way she remains always in service to the specular and the impossibility of representing her otherwise provide the theme and the pervasive melancholy of Eliot's work; her awareness of these problems, however, suggests one way feminism might work within the limits of this paradox.

Eliot writes in Middlemarch that "it is in these acts called trivialities that the seeds of joy are for ever wasted, until men and women look round with haggard faces at the devastation their own waste has made." 6 The waste of our lives, which, in a typical strategy of power, is made to seem our fault, is even more specifically blamed on woman. An attention to Eliot's work shows how one current approach of feminism, woman's attempt to embrace her association with the detailed refuse of the system representing her-its fragments and frivolities - or (another approach) to embrace her association with ultimate ruin, with nothing at all, with absence, invisibility, blankness-leaves her nonetheless hopelessly trapped. And perhaps we continue to read and revolt against Eliot's fiction because, in the face of that hopelessness, she writes on.

Before considering the status of detail, and of women, within that fiction, it might be helpful to outline the feminist context in which my reading proceeds. Just what are the problems recent critical debate has seen in the connections between women and the specular, feminism and the dominant order, that might help to

orization of the detail appears to be an essential aspect of that dismantling of Idealist metaphysics," she writes, "inseparable from the all too familiar story of the demise of classicism and the birth of realism" (3-4).

${ }^{6}$ George Eliot, Middlemarch, ed. W. J. Harvey (1965), ch. 42, p. 462; all future references to this book (hereafter abbreviated $M M$ ) will appear in the text. 
unravel similar connections-and problems-in Eliot's work? The invocation of the visual as a means to authority (and dominance) has been of special interest to feminists in their critique of a phallocentric order. In a move that for my purposes equates that orderand order itself - with realism because of their similar claims to objectivity, certainty, truth, feminist theorists such as Luce Irigaray have interrogated the circularity by which the specular is invoked to underwrite theory (theoria/speculation), interrogated the way phallocentrism attempts to secure its priority through its valorization of the visual order that supports it. Visual prominence becomes sexual privilege in an economy where the discovery of sexual difference is made (at least by Freud and our culture, if not by the structures of the unconscious) to depend on a sight, in a seamless tautology that then takes as standard what can be seen-that is, the phallic presence that determines the male as the defining category, judged against which the female becomes insufficient or lacking. ${ }^{7}$

Feminist film criticism has followed these suggestions to elaborate the way that the very gaze itself-the world view that determines the world-is male, associated with the male gender position and its claims for mastery, inflicting the hierarchy of gender division through its representation, and positioning and overmastering the woman as its object. In perhaps the best-known statement about the male gaze, Laura Mulvey investigates the phallocentrism of visual representation itself, contending that the very concept of vision is male. Mulvey argues that the structures of the unconscious manifested in patriarchy make the look male, the

7Freud, for example, "gladly" admitted to Abraham that "the female side of the problem is extraordinarily obscure to me" (quoted in Juliet Mitchell, "On Freud and the Distinction between the Sexes," in her Women: the Longest Revolution [1984], 223). For Freud's discussion of the role played by the sight of the penis in establishing the male as the determinative category of sexuality, see Sigmund Freud, "Some Psychical Consequences of the Anatomical Distinction between the Sexes," in vol. 19 of The Standard Edition of the Complete Psychological Works of Sigmund Freud, trans. James Strachey, 24 vols. (1953-74), p. 243-58; this edition hereafter abbreviated SE. In a critique of the scenario Freud paints in that essay, Mary Jacobus, following Jean Laplanche, points out that, even as Freud sketches it, the moment of decisive seeing meant to establish the penis as standard is actually one of "telling ambiguity"; Freud represses this uncertainty, brings it into line with the expectations of his argument (Mary Jacobus, Reading Woman: Essays in Feminist Criticism [1986], 113). For the most familiar and influential critique of male specularity, see Luce Irigaray, Speculum of the Other Woman, trans. Gillian C. Gill (1985). 
"to-be-looked-at-ness" female. ${ }^{8}$ Mulvey goes on to suggest that phallocentrism ultimately depends on the image of the castrated woman: "The meaning of woman is sexual difference, the absence of the penis as visually ascertainable."9 Because what woman reveals is castration, her very visibility both reassures the male order of its possession of the phallus and testifies to woman's exclusion from that order. ${ }^{10}$ Mulvey's response to male vision is to advocate that those of us in the position of woman refuse its lures if we cannot refuse to be its object-that we analyze how visual pleasure works to draw us into and hide its gender bias rather than simply succumbing to that pleasure.

Another approach to the specular, rather than refusing its pleasures, advocates an overelaboration of those pleasures, unsettling the specular by an excess of its own logic. This line of argument, making use of a deconstructive attention to the breakdown of categories of inner and outer, central and marginal, advocates an exaggeration of visual detail as a way to expose the phallocentrism of the visual; Jane Gallop, for example, suggests that a hyperattention to details unnoticed or overlooked by the reigning order unsettles its supposedly serene and eternal abstractions. Such attention exposes its own implication in power struggles that it wishes to ignore or to present as settled and done with, since their very existence puts its authority into question. Gallop argues that, as critics, we are driven to gain knowledge of a text when we feel powerless

8Mulvey, "Visual Pleasure," 11. For Mulvey, this is the cultural expression of the inequities built into our psychic structure. She writes: "In a world ordered by sexual imbalance, pleasure in looking has been split between active/male and passive/female. The determining male gaze projects its fantasy onto the female figure, which is styled accordingly" (11). Mary Jacobus agrees that the phallocentrism lies within structure-the very structures of representation: "What difference would it make if the viewer was 'she'? None at all; for what other 'way of seeing' has she than to see through his eyes, since his are the terms of representation itself?" (Reading Woman, 132).

9Mulvey, "Visual Pleasure," 13. In a formulation pertinent to the distinctions often made between the clarity of realism and the opacity of romance, Mulvey also contrasts woman's relation to the law with her obscurity: "Either she must gracefully give way to the word, the Name of the Father and the Law, or else struggle to keep her child down with her in the half-light of the imaginary" (7).

10Woman, as image of castration, paradoxically both threatens and allays anxiety. For a further discussion of this double movement, this time linked to that image of woman as the Medusa's head, see Neil Hertz, The End of the Line: Essays on Psychoanalysis and the Sublime (1985), 161-93. 
in the face of it. Our gesture of knowledge hides within its established certainties our once violent desire to understand and possess an object we are powerless to comprehend fully, to replace uncertainty, anxiety, and confusion with stability and order. ${ }^{11}$ Yet the unquestioning assumption of knowledge gains authority only by a ruse: "knowledge that has lost the truth of its roots in desire and aggression is in its very objectivity a lie."12 Minute attention to detail in our interpretations, Gallop argues, almost of necessity restores those roots, for the attempt "to divine secret and concealed things from unconsidered and unnoticed details, from the rubbish-heap, as it were, of our observations" - a phrase Gallop borrows from Freud-by transforming into significance the very refuse of meaning, unsettles the authority determining knowledge. ${ }^{13}$

Naomi Schor appropriates those subversive qualities of detail specifically for feminism. She writes that the traditional association of detail with the feminine reveals not just what "is perhaps most threatening about the detail: its tendency to subvert" but also the peculiar strength of the feminine position, which is similarly marginal and similarly insubordinate. ${ }^{14}$ According to such an approach, an attention to detail attests to and helps maintain the difference that, rather than simply entrapping women in phallogocentrism, might provide the best way for them to negotiate, and perhaps even change, its system of power. Schor writes: "before tearing down the cultural ghetto where the feminine has been confined and demeaned, we need to map its boundaries and excavate its foundations in order to salvage the usable relics and refuse of patriarchy, for to do so is perhaps the only chance we have to construct a post-deconstructionist society which will not simply reduplicate our own." 15 Through an attention to the representative details of gender division, which may be ultimately an attention to "anatomical difference" - and Schor's earlier essay advocating clitoral criticism suggests that she may be thinking of an anatomical

11Jane Gallop, "Psychoanalytic Criticism: Some Intimate Questions," Art in America 72 (November 1984): 11-13.

12Gallop, "Psychoanalytic Criticism," 13.

${ }^{13}$ Gallop, "Psychoanalytic Criticism," 13.

${ }^{14}$ Schor, Reading in Detail, 20.

${ }^{15}$ Schor, "Dreaming Dissymmetry: Barthes, Foucault, and Sexual Difference," in Men in Feminism, ed. Alice Jardine and Paul Smith (1987), 110. 
detail traditionally considered trivial according to male standards - Schor suggests that feminists must hold open the claim to feminine specificity. ${ }^{16}$ As feminists, we must focus on detail, Schor argues, to insist on sexual difference rather than indifferentiation, even if this means relying on a (revised) essentialism borrowed from traditional male views of women; such essentialism may be only provisional, she claims, but it is absolutely necessary in order to maintain any category of the female unappropriated to the male, if and when we ever reach the utopia we gesture to in our writing.

Although as feminists we may question how this call to recycle patriarachy's garbage is any different from what we do now (and we should remember that Gallop's suggestion to do so is itself already recycled from Freud), both critics suggest that we must of necessity try to unsettle from within the system of representation in which everyone is entrapped. ${ }^{17}$ Both identify an attention to detail as the way we can explicitly play up our implication in the system of power that produces significance, and in that way perhaps change its focus, change (but this is the problem), without reduplicating, that system.

The alternative suggestion, most familiarly associated with Irigaray, that we refuse such scrutiny (if not the category of sight) altogether relies on a similar strategy of playing up our implication within what we wish to reject and suggests that these seemingly opposed feminist approaches to the specular foundations of metaphysics - to play up or refuse its laws - are not really all that different. Rather than accepting the male visual standard, Irigaray's emphasis on the blind spots and peripheries outside male speculation is meant to call that standard's illusions into question: in her approach, woman is a dark continent that is "disquieting in its shadow" because she eludes the specular economy which determines meaning for those in power. ${ }^{18}$ The eluding of the specular means

16Schor refers to "anatomical difference" in "Dreaming Dissymmetry" (110). For her discussion of clitoral criticism, see Naomi Schor, Breaking the Chain: Woman, Theory, and French Realist Fiction (1985), 149-62.

${ }^{17}$ Gallop claims that this statement represents the side of Freud that is powerless, an illegitimate impostor, the Freud that feminists may find most attractive (Gallop, "Psychoanalytic Criticism," 13 and 15). But, even if true, it is important to emphasize that this reveals that Freud, too, is trapped in a system that does violence to him but does not unsettle that system.

${ }^{18}$ Irigaray, Speculum, 135. 
especially dispensing with particular details. Gallop, paraphrasing Irigaray, writes: "All clear statements are trapped in the same economy of values, in which clarity (oculocentrism) and univocity (the One) reign. Precision must be avoided, if the economy of the One is to be unsettled."19 This emphasis on the play of shadows obstructing or occluding direct perception is as much concerned with the marginal as one that stresses the almost hallucinatory clarity of vision that picks out details. And it poses the same question of whether it is possible to transform woman's traditional association with the marginal by playing it up.

Woman's relation to detail, then, represents a double bind in a variety of ways: she is caught in an association with details, whether they represent what is most evident or most impossible to see. In that way, she points both to the system and to what seems to deny or escape it. In any case, however, she remains defined by it. Notwithstanding Schor's celebration of what she sees as a specifically feminine compulsion to duplicity (another recycled banality about women?), this double bind is precisely what has been used to enable the inequities of gender division, the hierarchy between men and women. In these responses, the visual remains (as it seems it must) a central category underlying representation or epistemology, one with which those of us within representation (that is, everyone) cannot dispense, against which we continue to measure ourselves even as we try to imagine changing it or giving it up. ${ }^{20}$ It is because sight has become such a familiar synechdoche for what makes up our world, the very medium or means of construction with which we confuse that world, that the male order and its literary expressions attempt to lay claim to and control it. But is there any way to expose and disown the construction of the gaze, so that as feminists we can become free from what it represents, from what, after all, those inveterate disciples of phallogocentrism actually find more difficult to claim and control than they might like to admit?

One recent answer to this question has been no. In a move that, although useful, is also interesting in its need to deny significance

19Jane Gallop, The Daughter's Seduction: Feminism and Psychoanalysis (1982), 78.

${ }^{20}$ Irigaray's play of metaphor in Speculum, for example, foregrounds her awareness of such double binds, in its connections of women with fire and light as well as with darkness and shadow. 
to the particulars of gender difference, Foucauldian criticism, building on his discussion of surveillance, has worked from the assumption that the gaze is genderless-or, rather, that gender itself is another product of the social technologies that uphold an impersonal and regulating reconnaissance. To indict one gender position for exercising such power, it would follow, is just another instance in which the illusion of autonomy from power allows power to continue. $^{21}$ This argument is actually similar to the Lacanian interpretation of the status of the gaze, which (when more fully formulated than the feminist shorthand which sometimes simply equates the symbolic with male power) argues that the symbolic order reveals as well as rehearses gender inequities: the symbolic order is not equivalent to the male province; instead, it exposes that such a province is imaginary. This Lacanian reading of the symbolic foregrounds that men and women both are castrated, constituted within lack, and reveals the motivations and mechanisms by which women are simply made to stand for and draw off from men the problems of their own lack. ${ }^{22}$ Our feminist investigations may have unwittingly furthered the claims of phallocentrism, then, when they have accorded phallocentrism a power not actually proper to it, equating the male with the very system of dominance which it only desires (to appear) to control. In doing so we may have sometimes lost sight of the ways that the female, and feminism, are also in their own ways implicated in such a system, partaking of power even when it seems completely denied us.

II

Given this background of the specular, and our vexed relations to it as feminists, what can the connection between gender and modes

\footnotetext{
${ }^{21}$ For an expression of this view, see Mark Seltzer, "The Naturalist Machine," in Sex, Politics, and Science in the Nineteenth-Century Novel, Selected Papers from the English Institute, 1983-84, n. s. 10, ed. Ruth Bernard Yeazell (1986), 116-47. The ability to continue feminist criticism, given such assumptions, has plagued feminists interested in Foucault. For some tentative suggestions about how to do so, see Nancy Armstrong, Desire and Domestic Fiction: A Political History of the Novel (1987), and Foucault and Feminism: Reflections on Resistance, ed. Irene Diamond and Lee Quinby (1988).

${ }^{22}$ The best-known proponent of this more complicated reading of Lacan is Jane Gallop; see her Daughter's Seduction and Reading Lacan (1985).
} 
of literary representation add to this debate? Within literary representations, the evidence provided by seemingly insignificant details-the minutiae or innumerable particulars that make up the complexion of the larger text-has frequently been maintained as the guarantor of realism; a text's attention to detail is traditionally supposed to attest to its realism and is traditionally associated with the novel, not romance. Of course, as Naomi Schor suggests, a simple focus on the particular is different from the excessive heaping up of details, and an overabundance or excess of detail, although claimed by iconoclasts like Roland Barthes as representing precisely the "reality-effect," more conventionally has been seen as antirealistic. $^{23}$ Indeed the ornamentalism of schools like Orientalism have in literary history (in Vathek or even some of the works of Scott) been associated with (gothic) romance. Yet the association with realism of a certain moderated and controlled emphasis on detail continues to make sense despite the doubleness of detailnot because there is some kind of intrinsic and essential relation between whatever subjects hypothesize as reality and the particular or specific, but because realism asserts that relation in order to try to present itself as reality, not hypothesis. Such a maneuver denies its status as ideological production, screening as supposed fact the assumptions that govern it and screening too its own claims to govern that Foucault has suggested attend assertions of truth or knowledge. In order to make and mask such claims, realism claims a connection with detail because, as Foucault has also suggested, power invisibly infiltrates itself through details, through a multiplicity of small points of contact. ${ }^{24}$

Within literary texts, the motif of detail is consistently part of a more global metaphor of seeing. The critical argument that in a sense determined the modern importance of the novel and is most familiar to readers through James and Lubbock, the modern promoters of the form, is the argument for the effectiveness of the novelistic scene as seen, of what critics often call "showing" rather than "telling." The claim that in presenting a story "showing" is more dramatic and interesting because also more believable, more

\footnotetext{
${ }^{23}$ Roland Barthes, "The Reality Effect," trans. R. Carter, in French Literary Theory Today: A Reader, ed. Tzvetan Todorov (1982), 11-17.

${ }^{24}$ For a discussion of this kind of connection between details and the realistic novel, see Miller, The Novel and the Police, 17.
} 
lifelike, more true suggests how writing aligns itself with the visual and does so to claim for itself the authority of the empirical. It is almost by now a truism of criticism that the classical realism of nineteenth-century novels especially draws on metaphors of sight for its effect. Critics of the novel, such as J. Hillis Miller, Elizabeth Ermarth, and Catherine Belsey, have discussed realism's presentation of itself as a transparent optic, its reliance on what Belsey calls "vivid description and close attention to realistic detail" as a way seemingly to ground itself empirically. ${ }^{25}$ The rhetoric of the visual validates the form of realism by denying that it is a form. As Belsey suggests: "the term [realism] is useful in distinguishing between those forms which tend to efface their own textuality, their existence as discourse, and those which explicitly draw attention to it. Realism offers itself as transparent." ${ }^{26}$ Realism's emphasis on seeing makes it hard to see. Even in works by an author like Eliot, who is often explicitly careful to distinguish between realism and reality, to remind the reader now and then that the optic changes the picture, realism still presents itself as an optic, implicitly retaining the very mode of presentation (and the possible access to reality) it may temporarily question. ${ }^{27}$

Realism borrows from the visual in order to seem not just real but also true; it relies on the authority the visual seems to provide, the way it naturalizes ideological constructions into universal and accepted truths. As Stephen Heath writes: "where a discourse appeals directly to an image, to an immediacy of seeing, as a point of its argument or demonstration, one can be sure that all difference is being elided, that the unity of some accepted vision is being re-

${ }^{25}$ Catherine Belsey, "Re-Reading the Great Tradition," in Re-Reading English, ed. Peter Widdowson (1982), 123. See also her Critical Practice (1980). For a further discussion of the visual metaphors that realism relies on, see J. Hillis Miller, "Character in the Novel: A 'Real Illusion,' " in From Smollett to James: Studies in the Novel and Other Essays, Presented to Edgar Johnson, ed. Samuel I. Mintz, Alice Chandler, and Christopher Mulvey (1981), 277-85, and Elizabeth Deeds Ermarth, Realism and Consensus in the English Novel (1983).

26Belsey, Critical Practice, 51.

${ }^{27}$ For just one instance of Eliot's careful distinguishing, see the passage in chapter 17 of Adam Bede (a passage I discuss later in another context): "I aspire to give no more than a faithful account of men and things as they have mirrored themselves in my mind. The mirror is doubtless defective" (George Eliot, Adam Bede, ed. Stephen Gill [1980], ch. 17, p. 222); all future references to this book (hereafter abbreviated $A B$ ) will appear in the text. 
produced." 28 The techniques of realism-its omniscient all-seeing narrator, its emphasis on the particulars of that narrator's vision, the narrator's use of them to survey his world and detect and unravel its mysteries - are concerned "with seeing, with a seeing in detail," Mark Seltzer argues, to aid in our acceptance as subjects not just of one true unified vision but of an invisible supervision. ${ }^{29}$ For the visual has also been posited as an effective medium for imposing and maintaining social control: Foucault has described how the surveillance of the panopticon is the essential mechanism of the self-regulating system of power relations. By aligning itself with the visual, the classical realism of nineteenth-century novels like Eliot's (as a whole school of critics including D. A. Miller along with Seltzer has argued) participates in and promotes this system by attempting to contain it in itself. Classical realism is actually both a document of and effective propaganda for the system of power in which all subjects are inscribed.

In the English tradition, George Eliot's works have become synonymous with classical realism, and the relation of realism to the authority of the visual is a consistent focus that they investigate as well as rely on. Like the other novelists I consider, Eliot uses romance to define her own realistic novels; in her novels, the claim of realism to the precision and clarity of specularity contrasts with a rhetoric associating the dizzying profusion of details, or their indistinctness, with romance. Yet, as for other novelists, Eliot's realism cannot keep separate from what it casts as its opposite. In The Mill on the Floss, describing Maggie "battling with the old shadowy enemies that were forever slain and rising again" (MF.7.5.644), Eliot describes too the struggle between the realism of her novels and an undispatchable romance within them. Eliot locates the terms of the dynamic I have been charting a little differently from the other novelists I have considered: between what critics call modes, not genres, attitudes or presentation rather than types or forms. ${ }^{30}$ Eliot means for her dominant mode of presentation to ensure the primacy of her genre, the novel, but romance is a shadowy enemy, always rising again, because, in fighting it, realism is

28Stephen Heath, "Difference," Screen 19 (1978): 53.

${ }^{29}$ Seltzer, Henry James, 50.

${ }^{30}$ For a discussion of the difference between modes and genres, see Northrop Frye, Anatomy of Criticism: Four Essays (1957), 95-99, 246-326. 
fighting its own shadow. Like all the heroines I have analyzed, Maggie embodies this struggle in herself: "her thoughts generally were the oddest mixture of clear-eyed acumen and blind dreams" (1.11.177). Yet, although the novel attempts to reproduce this as a battle, presenting the "sense of opposing elements, of which a fierce collision is imminent" (5.1.394), their mixture in Maggie also suggests their kinship: as the title to the chapter in which Maggie escapes to the gypsies ironically suggests, Maggie cannot run away from her shadow - the differences between realism and romance cannot be maintained. The struggle between a realism and a romance that are ultimately indistinguishable exposes how the fight between them, conducted on the site of the woman, is rigged. No matter which side wins, the struggle she embodies does not liberate but remains dangerous to her, ultimately deadly-the moral Maggie's end poses to her cautionary tale.

The investigation of this double bind seems central to Eliot's fiction, for she admits both warring factions easily into her work. Eliot's derision of romance is much less strict than (although often still as virulent as) that of the other novelists I have considered, and her definition of realism in her essays and letters outlines a mode of representation that is explicitly problematic and contradictory. Adam Bede and The Mill on the Floss-early novels in which Eliot maps out her realism-never completely dispel romance, although in them readers find Eliot's strongest disclaimers against it; by the end of her career, in Daniel Deronda, disclaimer has softened to conciliation: Eliot writes, for example, that although "to say that Deronda was romantic would be to misrepresent him," still, he has "a fervour which made him easily find poetry and romance among the events of everyday life. And perhaps poetry and romance are as plentiful as ever in the world. . . They exist very easily in the same room with the microscope." 31 Romance, as present in the everyday life of her first fiction as it is in the later works, may be more intensely denied early on to deny the initial shock of disillusionment and frustration-and failure-in attempting to imagine an alternative to realism and the order it represents.

Eliot's reference to the microscope in the previous passage indi-

${ }^{31}$ George Eliot, Daniel Deronda, ed. Barbara Hardy (1967), ch. 19, p. 245. All further references to this book (hereafter abbreviated $D D$ ) will appear in the text. 
cates the initial differences her fiction charts between realism and romance. Her realism is based in an optic that focuses on "minute reality." ${ }^{2}$ In contrast, Eliot seems to imply (and critics have agreed), romance lacks such minute particulars. R. E. Francillon, in an early review of Daniel Deronda, writes:

It is precisely in the detailed elaboration of the little, characteristic, everyday things which procure universal acceptance for a book at once that we are most conscious of an unusual want in Daniel Deronda. In this respect also it is distinctively of the nature of the Romance, which tends to bring universal and essential things into prominence, and to leave accidental and transitory things on one side. It will never require a department in the museum. 33

The "unusual want" of details in romance may provide one way to elude what Foucault might call the micro-optics of power-the anonymous scrutiny of everyday things which objectifies and masters them-one way to escape being institutionally exhibited ("it will never require a department in the museum")—exhibited, say, through an institution of literary representation like realism (as Eliot might hope that Dorothea's "indefiniteness" will keep her from being exhibited to the male gaze in the Hall of Statues in the Museum in Rome).

The traditional association of romance with the essential and universal that we find in Francillon's review suggests that romance too remains essentializing and dangerous. Romance's "want" is just as dangerous as realism's completeness because it still accedes to the same law, which sees only what it looks for or nothing at all-which sees only itself and thereby makes itself universal. Romance remains connected to realism; it also "exists very easily in the same room with the microscope." The microscope in its scrutiny of detail continues their connection for it also turns realism into romance; it transforms "little, characteristic, everyday things" into the whole field of vision, making the everyday seem unfamiliar, the little larger than life, magnifying- "bringing into

32"John Blackwood to George Eliot, Edinburgh, 31 March 1858," in vol. 2 of The George Eliot Letters, ed. Gordon S. Haight, 9 vols. (1954-78), p. 445.

33 "George Eliot's First Romance," from the Gentleman's Magazine, in George Eliot: The Critical Heritage, ed. David Carroll (1971), 395. 
prominence" - what is supposedly "essential," making it into the "universal." The general and particular remain inseparable in Eliot's fiction, for, as Eliot has Lydgate explain, "a man's mind must be continually expanding and shrinking between the whole human horizon and the horizon of an object-glass" (MM.63.690). This confusion of realism and romance-Eliot's hesitation between them-may suggest that there is no real choice.

Reviewing Ruskin's Modern Painters III, Eliot does seem to choose realism, to define it in a way that critics have aptly applied to her own novels: "The truth of infinite value that [Ruskin] teaches is realism - the doctrine that all truth and beauty are to be attained by a humble and faithful study of nature, and not by substituting vague forms, bred by imagination on the mists of feeling, in place of definite substantial reality." ${ }^{34}$ In borrowing her idea of realism from a doctrine about painting, Eliot's verbal system is directly predicated on an analogy with a visual one-one that celebrates the definite, the detailed. Eliot's definition is also in keeping with the Victorian critical consensus on realism. That critic most important to Eliot, George Henry Lewes, similarly equates realism with descriptive detail. In a letter to Eliot's publisher, John Blackwood, about a story that she wrote not long after the essay on Ruskin, "Janet's Repentance." Lewes admits: "What you say about the hacknied nature of the clergyman's story is perfectly true; and it appears all the more hacknied because the rest of the tale is so entirely original; but the vaguer such a story, the more hacknied it would necessarily appear; details give an air of reality, and I could have wished G.E. had been more detailed." ${ }^{35}$ Similarly, Edith Simcox, reviewing Middlemarch, assumes by "realism, the positive background of fact." 36

${ }^{34}$ [George Eliot], "Art and Belles Lettres," Westminster Review n.s. 9 (January and April 1856): 626.

35"George Henry Lewes to John Blackwood, Richmond, [23? August? 1857]," in Letters, 2: 378 .

${ }^{36} \mathrm{H}$. Lawrenny [Edith Simcox], Review of Middlemarch, from the Academy, in Carroll, George Eliot: The Critical Heritage, 324. Modern literary critics assume the same equation, especially when distinguishing realism from romance. George Levine, like Lewes, uses detail in opposing realism to the vague and hackneyed. Victorian novelists, Levine writes, "seem to take pleasure in the details they invoke from outside the patterning conventions of romance. And the great realistic fictions are exuberant with details" (Levine, The Realistic Imagination: English Fiction from Frankenstein to Lady Chatterly [1981], 21). Levine goes on to suggest that realism, in 
Yet these literary critics do not assert a simple connection between details and what Lewes calls the "air of reality"; Lewes himself, for instance, is especially critical of what he terms the "detailism which calls itself realism" - a false realism that has gone too far, by piling up arbitrary details, and too many of them, at the expense of meaning. ${ }^{37}$ Like Eliot, he believes that "all Art depends on Vision," but he goes on to elaborate that "the rage for 'realism,' which is healthy in as far as it insists on truth, has become unhealthy, in as far as it confounds truth with familiarity, and predominance of unessential details," a predominance that ultimately calls that realism into question. ${ }^{38}$ Lewes finds especially unhealthy and unessential those details taken from what he sees as low subjects; in an appeal to class-consciousness, he dismisses a realism built on details that might delight tailors and upholsterers. ${ }^{39}$ That

fact, makes use of detail in order to displace romance-one of its "major devices" is "the reduction of the romantic to the banal by means of the translation of a rhetorically inflated cliche into a set of unattractive details" (281). Levine elsewhere particularly links Eliot's early realism to "confident empiricism," "assured rendering," and "clear perception" (Levine, "George Eliot's Hypothesis of Reality," Nineteenth-Century Fiction 35 [June 1980]: 3). Lennard J. Davis also argues that "the romancer's view of the world is thus based on the effacing of the offending or nonconforming fact or event and the creation of the ideal, the paradigmatic, the traditional. The writer of novels, on the other hand, sees narrative as more oriented to the specific, the particular, the eccentric, the factual" (Davis, Factual Fictions: The Origins of the English Novel [1983], 33). Jonathan R. Quick suggests that when Eliot intentionally strives for romance, as in Silas Marner, she abandons "the sharp precision and fullness of detail" of her realistic works for a "darkened, dreamlike atmosphere" (Quick, "Silas Marner as Romance: The Example of Hawthorne," Nineteenth-Century Fiction 29 [December 1974]: 291). For Eliot's assumption of romance as visually obscure, see, for instance, her criticism of the popular novelist Fredrika Bremer's "pink haze of visions and romance," in "[Three Novels]," in The Essays of George Eliot, ed. Thomas Pinney (1963), 332. This passage is interesting, for in it Eliot is discussing Bremer's treatment of "the cause of women," which Eliot wishes had more "attention to detail" and more "light of common day" than romantic haze.

${ }^{37}$ George Henry Lewes, The Principles of Success in Literature, ed. Fred N. Scott (1891), 83. These essays were originally published in the journal Lewes edited, the Fortnightly Review, from May through November of 1865 , and were first published in book form in 1885. For a discussion of Lewes's detailism, see Richard Stang, The Theory of the Novel in England, 1850-1870 (1959), 174.

38Lewes, Principles of Success, 84 . He writes that "I wish to guard the Principle of Vision from certain misconceptions which might arise on a simple statement of it. The principle insists on the artist assuring himself that he distinctly sees what he attempts to represent. What he sees, and how he represents it, depend on other principles" (85).

${ }^{39}$ Lewes, Principles of Success, 84-85. Lewes writes: "The painter who devotes years to a work representing modern life, yet calls for even more attention to a 
Lewes felt he had to outline a suspect detailism somehow different from Eliot's use of detail, and that he did so in a rhetoric whose appeal to bias tried to mask the problems of its logic, indicate the difficulty of claiming "the truth of infinite value" that Eliot wants to ascribe to detail and reveal that such problems worried Eliot's circle. Yet the paradoxical status of detail, while it calls the certainties of realism into question, does not necessarily overturn the visual system; such contradictions may be what allow that system to flourish by retaining it as the standard, keeping all of us in it locked between alternatives of what we can or cannot see. Eliot's very difficulty is finding out how to negotiate these alternatives.

The validity of Eliot's realism is also uncertain because its own relation with visual detail is vexed-vexed by what Barbara Hardy has best described as Eliot's sense of the "disenchanted day-lit room," her discomfort with solid particulars. ${ }^{40}$ The "definite substantial reality" that Eliot praises in Ruskin becomes "the dreary persistence of definite measurable reality" in "Janet's Repentance," with its "oppressive distinctness" of "details," and also becomes the "hard, inevitable reality" of Adam Bede, heavy too with the weight of "details" (AB.38.444). ${ }^{41}$ Hardy suggests that it is only Eliot's characters who recoil from the "oppressive narrowness" (MF.4.1.363) of the world of Eliot's realism and that acceptance of this world is part of Eliot's moral for them. Yet surely Eliot herself

waistcoat than to the face of a philosopher, may exhibit truth of detail which will delight the tailor-mind, but he is defective in artistic truth, because he ought to be representing something higher than waistcoats. . . if a man means to paint upholstery, by all means let him paint it so as to delight and deceive an upholsterer; but if he means to paint a human tragedy, the upholsterer must be subordinate" (84-85).

40Barbara Hardy, The Novels of George Eliot: A Study in Form (1959), 190. Eliot's reliance on but discomfort with descriptive detail may have been what kept her from writing for years. In "How I Came to Write Fiction," she records that although she felt at "ease in the descriptive parts of a novel," she realized that scene painting and detail were not groundwork enough for fiction ("George Eliot Journal, Richmond, 6 December 1857," in Letters, 2:406-7). Eliot uneasily proceeded to build her realism on the very quality she found troubling, and -although she admitted her doubts in her journal-she defended her emphasis on description against others. She wrote to Charles Bray about "Three Months in Weimar": "Don't say anything about it, for to people who do not enjoy description of scenery it will seem very tame and stupid, and I really think a taste for descriptive writing is the rarest of all tastes among ordinary people" ("George Eliot to Charles Bray, East Sheen, 12 May 1855," in Letters, 2:201).

${ }^{41 G e o r g e ~ E l i o t, ~ " J a n e t ' s ~ R e p e n t a n c e, " ~ i n ~ S c e n e s ~ o f ~ C l e r i c a l ~ L i f e, ~ e d . ~ D a v i d ~ L o d g e ~}$ (1973), ch. 16, p. 349. 
recoils; her rebellion against that realism is responsible for the (realistically) implausible ending of The Mill on the Floss, for instance. ${ }^{42}$

Eliot had reason to be uneasy with detail, for although her books were immediately praised, by Blackwood for example, for the effect of their "minute touches," those touches could also backfire. ${ }^{43}$ Blackwood first criticized her work because of its visual particularity; he found that in "Amos Barton" Eliot tried "too much to explain the characters of [her] actors by descriptions" and that she ruined the deathbed scene by "specifying so minutely."44 None of Eliot's novels escaped criticism of this sort. Perhaps the best-known criticism in this vein is Henry James's, who found Middlemarch "a treasure-house of details, but it is an indifferent whole." ${ }^{45}$ Ruskin, rather than recognizing his own realism in Eliot's project, found her details common and trashy, using against her both the class prejudice and the image of unhealthiness that Lewes associated with detailism - to Ruskin, her details were "the sweepings out of a Pentonville omnibus" and the "blotches, burrs and pimples" in a "study of cutaneous disease." 46 Rather than providing a solution to the very problems that Lewes outlined, Eliot's realism repeated those problems despite itself.

Coincident with Eliot's association of detail and realism is a competing association of detail and romance, drawn from another writer Eliot admired, Sir Walter Scott, whom Lewes called her "longestvenerated and best-loved Romancist" in his inscription in the set of

${ }^{42}$ For a feminist interpretation of that implausibility, see Nancy K. Miller, "Emphasis Added: Plots and Plausibilities in Women's Fiction," PMLA 96 (January 1981): $36-48$, especially $44-47$.

43“John Blackwood to George Eliot, Edinburgh, 3 November 1858," in Letters, 2: 492.

44 "John Blackwood to George Henry Lewes, Edinburgh, 12 November 1856," in Letters, 2: 272.

${ }^{45}$ Henry James, Unsigned Review of Middlemarch, from the Galaxy, in Carroll, George Eliot: The Critical Heritage, 353.

46John Ruskin, from Nineteenth-Century, in Carroll, George Eliot: The Critical Heritage, 167. For more of such criticism of Eliot's novels, see, for example, the unsigned review of The Mill on the Floss from the Dublin University Magazine, which criticized its "photographic pettiness" and its "heaping-up of meaningless details" (in Carroll, George Eliot: The Critical Heritage, 145, 146). See also R. H. Hutton's unsigned review of Felix Holt, from the Spectator, which finds fault with its "overflowing affluence of lively and striking detail" (in Carroll, George Eliot: The Critical Heritage, 258). 
Waverley novels he gave to her. ${ }^{47}$ Scott writes in Waverley: "The most romantic parts of this narrative are precisely those which have a foundation in fact." 48 As Donald Stone tells us, "William Hazlitt said of Scott what later commentators observed of Dickens and George Eliot: 'Sir Walter has found out (oh, rare discovery) that facts are better than fiction; that there is no romance like the romance of real life.'"49 From the first, critics did indeed observe this of Eliot; a reviewer of Scenes of Clerical Life approved its "just appreciation of the romance of reality." 50 Eliot was so influenced by this model that, while she was working on the book that she herself termed a romance, Romola, Lewes wrote to Blackwood: "when you see her, mind your care is to discountenance the idea of a Romance being the product of an Encyclopaedia." ${ }^{11}$ This heaping up of everyday reality, facts, detail (a totalizing overabundance of it, as the reference to the Encyclopedia suggests), points to the way romance can also be determined by the empirical (even as it stretches its limits).

The title character of Adam Bede seems to provide the steadiest support for the empiricism of the novel, its plain, commonsensical realism; Adam is himself plain and commonsensical, at home with facts and the things of the world, "observant of the objects round him" (38.438). Adam's attention to detail, which directly aligns him with the specular law of realism, also aligns him with the legal system in the novel: Dinah sees him as a kind of patriarch (as his name suggests), and he is specifically like the lawyer in Hetty's case, who is also observant, "a cute fellow, with an eye that 'ud pick the needles out of the hay in no time" (42.473). But the law in this story is crucial in trying and condemning Hetty and, through this, the novel suggests that Adam's relation to the law is also double-edged. This law, in punishing Hetty, also contravenes his own desires. Her suffering calls his adherence to it into question, shows him his own inflexibility and culpability. Adam's pain is

${ }^{47}$ Quoted in Gordon S. Haight, George Eliot: A Biography (1968), 319.

48Sir Walter Scott, Waverley, vol. 2 of The Large Paper Edition of the Works of Sir Walter Scott, 50 vols. (1912-13), p. 311.

${ }^{49}$ Donald D. Stone, The Romantic Impulse in Victorian Fiction (1980), 13.

50Unsigned review of Scenes of Clerical Life, from the Atlantic Monthly, in Carroll, George Eliot: The Critical Heritage, 66.

51 "George Henry Lewes to John Blackwood, London, [14 December 1861]," in Letters, 3:474. 
Eliot's lesson for him-he must bend under the same inflexible rule that he has sanctioned for others, and, from his own suffering, he gains forbearance and sympathy for them. Yet Adam's moral lesson - that those who uphold the law are themselves guilty and must suffer under it-points to the doubleness within Eliot's realism and begins to put the idea of its law (as something a subject might be above or outside) into question.

It is not so much Adam's as Hetty's example that reveals as an illusion our hopes as subjects of maintaining the category of law as something we can either claim or transgress. " 'Law?' " asks Bartle Massey. "'What's the use o' law when a man's once such a fool as to let a woman into his house?' " (21.284). Adam suffers at Hetty's expense; she becomes the little piece of trash discarded to save the rest. While comforting Adam in his sorrow over Hetty's crime, the rector, Mr. Irwin, suggests that "if the evidence should tell too strongly against her . . . we may still hope for a pardon' " (40.458). Critics have argued that the evidence tells too strongly indeed: the kind of detail associated with Adam and from which he draws strength explicitly becomes evidence, the circumstantial facts that convict Hetty at her trial and save Adam from her. Hetty falls victim to the war of detail fought between realism and romance. She is not pardoned but sacrificed, it seems, for nothing more than a handshake between two men; her death facilitates the Girardian reconciliation that takes place between Adam and Arthur at novel's end. 52

The violence of Eliot's realism enacted on scapegoats like Hetty is meant to purge it of romance, which it depicts as deviant and onto which it projects (and hence denies) its own violence. Beginning with "Amos Barton," Eliot associates the romantic and the criminal: she builds her first story around a realistic, unheroic hero who is so partly because he "had no undetected crime within his breast." 53 Adam Bede's narrator wryly suggests that that book is realistic too in part because "romantic criminals [aren't] half so frequent as your common labourer" (AB.17.225). In The Mill on the Floss, Aunt Moss's farm is Maggie's romantic retreat, her "Alsatia,

\footnotetext{
${ }^{52}$ For a discussion of the connection between men in this novel, see Eve Kosofsky Sedgwick, Between Men: English Literature and Male Homosocial Desire (1985), 134-60.

${ }^{53}$ George Eliot, "The Sad Fortunes of the Rev. Amos Barton," in her Scenes of Clerical Life, ch. 5, p. 80 .
} 
where she was out of the reach of the law" (MF.1.8.139), and the narrator suspects readers may find that the realism of the novel is "sordid" because it has none of "the dark shadows of misery and crime" they can find in romance (MF.4.1.362). Eliot uses this metaphor of the shadowy underworld to reiterate that romance is outside her work, eclipsed by her realism. Yet she has her own cast of romantic criminals, her ladies with daggers. They themselves remain marginal to her stories (as Madame Laure does), or their crimes remain indefinite and unacted (as Gwendolen's or Caterina's do), yet what she defines as romance invades Eliot's work nonetheless in their characterization. Whether the violence her book portrays is defined as legitimate-as in the court's penaltyor illegitimate-as in the women's revenge-it is violence all the same, putting into question the differences between the modes that practice it. That the violence ultimately rebounds onto women like Hetty and Maggie, killed off to resolve the impossible demands of their stories, suggests that their sacrifice is meant to hide the seamlessness of an order that wishes to appear divided. They supposedly perish because of their association with romance, but such violence is all that awaits them in the world of realism as well.

Hetty is expressly made to seem a romantic criminal; she kills her baby partly to preserve her vague romances about Arthur, to deny the reality of what has happened to her, and Eliot indicts such romance through the setting of Hetty's trial: the story pauses to tell us that the trial takes place in what was once a kind of Arthurian court (linking Hetty's dreams about her own particular Arthur and conventional Arthurian romances). But the court has been taken over by Eliot's realism, ironically transformed into a court of law (AB.43.476). Eliot seems, and has angered some readers by seeming, a firm supporter of the law that Hetty and the others violate, on the side of Adam and the order he claims. ${ }^{54}$ Yet, as feminist

\footnotetext{
${ }^{54}$ At her most censorious, Eliot, in depicting Bartle Massey's dog's solicitude for her puppies, goes so far as to imply that Hetty's crime is against the law of nature as well as that of man-Hetty, Eliot suggests, is not after all so much like the cute little animal to which the narrator and characters have compared her and should therefore forfeit the small sympathy readers were allowed to give her for that similarity. But Eliot mitigates her disapproval a little by putting blame elsewhere than on these women. Grandcourt is the one who drives Gwendolen (almost) into crime. Readers can blame Caterina's passion on Wycroft and Cheverals, who aren't "romantic" enough to adopt her (George Eliot, "Mr. Gilfil's Love-Story," in her Scenes of Clerical
} 
critics have pointed out, the idea of law itself also comes into question in Eliot's work: another set of villains in The Mill on the Floss are the men of maxims, guided "solely by general rules, thinking that these will lead them to justice by a ready-made patent method" $(M F .7 .2 .628) .{ }^{55}$

Questioning the law, however, does nothing to save Hetty. Eliot may need to shatter Hetty's romance building in order to preserve the very legend of George Eliot, a self carefully constructed through her novels and other writings. In a letter written during her evangelical period, the young Mariann Evans works out her relation to writing by decrying the effects of fiction-both novels and romances-in language that foreshadows George Eliot's depiction of Hetty and outlines the complications that inform her later work:

The Scriptural declaration, "As face answereth to face in a glass, so the heart of man to man," will exonerate me from the charge of uncharitableness or too high an estimate of myself if I venture to believe that the same causes which exist in my own breast to render novels and romances pernicious have their counterpart in that of every fellow-creature.

I am I confess not an impartial member of a jury in this case for I owe the culprits a grudge for injuries inflicted on myself. I shall carry to my grave the mental diseases with which they have contaminated me. When I was quite a little child I could not be satisfied with the things around me; I was constantly living in a world of my own creation, and was quite contented to have no companions that I might be left to my own musings and imagine scenes in which I was chief actress. Conceive what a character novels would give to these Utopias. I was early supplied with them . . . and of course I made use of the materials they supplied for building my castles in the air. 56

The wishful opening of this passage- "as face answereth to face in a glass, so the heart of man to man" - exposes one anxiety of Eliot's

Life, ch. 3, p. 152). Readers can even recuperate Hetty and Madame Laure, by discovering in them, as Gilbert and Gubar do with Eliot's other transgressors, her own covert resistance to the constraints of the established system; see Sandra M. Gilbert and Susan Gubar, The Madwoman in the Attic: The Woman Writer and the Nineteenth-Century Literary Imagination (1979), 443-535, for a discussion of the image of the veil in Eliot and of Eliot's veiled resistance to patriarchy.

55See Nancy K. Miller, "Emphasis Added," and Jacobus, Reading Woman, 62-79.

56"George Eliot to Maria Lewis, Griff, 16 [March 1839]," in Letters, 1: 22. 
that aligns her with Hetty; the young writer here insists that she sees in the mirror more than just her own face-she exonerates herself from the "high estimate of self" of which Eliot later convicts Hetty. The mirror gives her that connection with others that becomes the moral law of Eliot's realism, a position of truth from which she can denounce other fiction. Yet the wishfulness suggests that Hetty's narcissism and her resulting delusive dreams, which Eliot outlaws from her fiction, are outlawed because Eliot believes them to be such present dangers. The "confession" of this letter suggests the writer's identification with Hetty, for whom confession is so important in Adam Bede-by confessing, that writer shows that she is the accused as well as the judge, as much in Hetty's position as the one who sets her up.

When judging, Eliot confesses that she "is not an impartial member of a jury" in her prosecution of fiction in this letter, nor is she later in prosecuting Hetty in Adam Bede: by denouncing romance in that novel, she hopes to protect her own realism from the "contamination" she notes in her letter; she would also like to believe that the realism of her novels is built not of air but of solid concrete detail. Yet she admits here that such a foundation is not enough, that she is drawn to her vapory imaginings- "I could not be satisfied with the things around me."

Hetty bears the brunt of her grudge; she is sacrificed, supposedly exorcising romantic influences and testifying to the preeminence and validity of realism, in order to create a world in which the hearts of men do answer to each other (as Adam's and Arthur's do), where men can be contented with their companions because such companionship does not enmire them in power relations. The desire for this utopia is supposedly common to every fellow creature but can be represented only as between fellows, as a world of men: this remains perhaps the most pernicious limitation of (Eliot's) fiction (although, in exposing this limit, Eliot also exposes that it is by no means uniquely hers). Eliot's authorial self gains the consolation of autonomy from a world of strife and waste only by identifying with the male order, becoming George Eliot.

Yet the author of Adam Bede is no more able, by embracing a powerful realism or subversive romance, to write herself out of the structures of representation than Hetty is able to transform her world to her desires. With its opening sentences, borrowing an image from the Arabian Nights, the book's endeavor is associated 
with Hetty: as critics have long remarked, the sorcerer's drop of ink (AB.1.49), in which the writer sees her visions, reappears as Hetty's "black pool" (37.435), in which she longs to end all vision. Even realism's manifesto in chapter 17 , through its imagery, ties that realism to the romantic Hetty and back to the letter about the dangers of fiction. Eliot writes: "I aspire to give no more than a faithful account of men and things as they have mirrored themselves in my mind. The mirror is doubtless defective; the outlines will sometimes be disturbed; the reflection faint or confused; but I feel as much bound to tell you, as precisely as I can, what that reflection is, as if I were in the witness-box narrating my experience on oath" (17.221). The defective mirror of realism cannot be divorced from the spotty mirror before which Hetty looks at herself and dreams her romances (15.194-202). In speaking from "the witness-box," Eliot takes an oath that guarantees her "preciseness," her commitment to the detailed account of realism, just as the oaths of those in the witness-box in Adam Bede convict Hetty and dispel the romance she represents. But Eliot's oath has already been put into question by her earlier confession of partiality; because of Eliot's identification with Hetty, by convicting her, she convicts herself. She remains a culprit and a victim even as she tries to exercise power.

As Hetty's importance in the struggle of realism with romance suggests, woman's definition is a crucial issue in Eliot's work. As she began to prepare for writing fiction, Eliot thought constantly about the woman question, projecting more articles about it than she could write and reading and editing the articles of others, and her fiction expressly takes a woman's life as its starting point. ${ }^{57}$

Woman is more than just the basis for Eliot's stories, however; she also figures the problems of representation that are the focus of

57Eliot published the essays "Woman in France" (1854) and "Silly Novels by Lady Novelists" (1856), as well as reviews of women writers. She projected publishing "Ideals of Womankind" and "Women in Germany" (see "George Eliot to John Chapman, Berlin, 9 January [1855]," in Letters, 2: 190). She edited Chapman's 1855 article, "The Position of Women in Barbarism and among the Ancients." Lewes's "The Lady Novelists" was published in 1852 . For examples of the explicit reliance of her fiction on women's stories, see the claim in The Mill on the Floss that it is grounding its tale in a woman's vicissitudes (6.3.494) or see, in Middlemarch, the narrator's comparison of herself to Herodotus, "who also, in telling what had been, thought it well to take a woman's lot for his starting-point" (11.123). 
Eliot's work. In an early essay outlining the nature of realism, "The Natural History of German Life," in a vignette later echoed in Adam Bede (AB.19.253), Eliot emphasizes the importance of woman:

Observe a company of haymakers. When you see them at a distance... you pronounce the scene "smiling," and you think these companions in labour must be as bright and cheerful as the picture to which they give animation. Approach nearer, and you will certainly find that haymaking time is a time for joking, especially if there are women among the labourers; but the coarse laugh that bursts out every now and then, and expresses the triumphant taunt, is as far as possible from your conception of idyllic merriment. 58

Such scene painting, what Eliot calls in Middlemarch "that softening influence of the fine arts which makes other people's hardships picturesque" (39.429), hides that the relations between such "companions" are power relations. The introduction of gender-for Eliot, as for her culture, the differences of gender are represented by women-into the specular exposes the logic of the specular. Although it is unclear whether women give or receive the triumphant taunt, the implication is that gender differences introduce conflict, introduce the idea of triumph or defeat. Minute observation and women converge; woman becomes the telling detail that changes the picture from a vague idyll, viewed at a distance, to a rendering that can only be coarse in its accuracy and comes too close to us for comfort. Eliot's hesitation in aligning herself with either perspective is made explicit. The narrator here prefers only to gesture to but not examine this picture, only to shatter what might be vague romance while withholding scrutiny of what might be hardships-and, likely, women's hardships.

Yet, despite a reluctance to take sides, in exposing the attempt to claim and purge the specular order by scapegoating its problems onto women, Eliot's fiction repeats that scapegoating. Adam Bede deplores Hetty's narcissism, her posing before her mirror. But in admiring herself as a visual object and attempting to look like the portraits of ladies at the Chase, Hetty is only doing what the novel

${ }^{58}$ George Eliot, "The Natural History of German Life," in Pinney, Essays of George Eliot, 269 . 
itself does to her: it presents her as something to look at, a picture, an object-her trial reveals that she is rarely out of someone's sight. Blackwood's reaction to her is typical: "Hetty is a wonderful piece of painting. One seems to see the little villain." 59 The novel's association of women with the descriptive detail of its realism makes Hetty into a spectacle; in flaunting her looks, she only acts out its logic. ${ }^{60}$

Adam is the spokesman for the connection in the novel between woman and the naked fact. When Hetty puts a rose in her hair to imitate a picture, Adam explicitly formulates the place of woman in the specular economy: "Ah . . . that's like the ladies in the pictures at the Chase; they've mostly got flowers or feathers or gold things i' their hair, but somehow I don't like to see 'em; they allays put me $i^{\prime}$ mind $o^{\prime}$ the painted woman outside the shows at Treddles'on fair" (AB.20.269). Adam's equation exposes the logic of the specular order. Painted women (pictures) ultimately equal painted women (prostitutes). Although Adam hates to admit it of Hetty (yet it is what draws him to her), woman as object is inevitably a sexual object.

Woman's association with detail quickly becomes her reduction to anatomical detail, as the reaction of Eliot's contemporary critics to her minuteness indicates. Their criticism of what they saw as the excessive facts within Eliot's work frequently became criticism of what the Examiner called an "almost obstetric accuracy of detail," what they all felt was Eliot's overemphasis on the facts of life. ${ }^{61}$

\footnotetext{
${ }^{59}$ From a letter dated ${ }_{4}$ October 1858 , quoted in Haight, George Eliot: A Biography, 265.

60For Hetty as spectacle: see "Hetty was quite used to the thought that people liked to look at her" (AB.9.141); "She's like a pictur in a shop-winder" (36.423); and see also Arthur remembering Hetty as a "picture" (44.485). Hetty also regards herself from the position of "an invisible spectator" (15.195). Catherine Belsey argues that woman as spectacle, in the case of Gwendolen, grows from "the social production of femininity" as well as from the production of realism (Belsey, "Rereading," 132). For the standard discussion of woman as spectacle, see John Berger (with Sven Blomberg, Chris Fox, Michael Dibb, Richard Hollis), Ways of Seeing (1972), 45-64.

61From the Examiner, quoted in Carroll, George Eliot: The Critical Heritage, 11. See also the unsigned review of Scenes of Clerical Life, from the Saturday Review, which finds that Hetty's story "read[s] like the rough notes of a man-midwife's conversations with a bride" (in Carroll, George Eliot: The Critical Heritage, 76); or the unsigned review of The Mill on the Floss, from the same journal, which says that Eliot and other women writers "linger on the description of the physical sensations that
} 
That the facts of life the specular builds on are necessarily biological is implied in the assumptions informing Eliot's conception of representation. The nineteenth-century positivism that ascribed its authority to empiricism - to sensory data as the ultimate base of observation-also, as recent critics have shown, legislated that anatomy equals destiny, that "for women biology controlled social destiny." 62 This hidden trap of essentialism, so inimical to women, is built into Eliot's fiction; her realism seems to embrace it, and her romance is unable to avoid or overturn it. ${ }^{63}$

accompany the meeting of hearts in love" (in Carroll, George Eliot: The Critical Heritage, 188); or the unsigned review of Silas Marner, from the Westminster Review, which criticizes Eliot's "somewhat objectionable use of physiological images" (in Carroll, George Eliot: The Critical Heritage, 188). Critics still emphasize anatomical detail in Eliot's fiction, as in Ellen Moers's discussion of the significance of the Red Deeps (Literary Women [1976; 1985], 252-57) or the current debate over Daniel Deronda's circumcision (see Cynthia Chase, "The Decomposition of Elephants: Double-Reading Daniel Deronda," PMLA 93 [March 1978], 215-27; K. M. Newton, "Daniel Deronda and Circumcision," Essays in Criticism 31 [October 1981]: 313-27; and Mary Wilson Carpenter, "'A Bit of Her Flesh': Circumcision and 'The Significance of the Phallus' in Daniel Deronda," Genders 1 [March 1988]: 1-23).

62Jill Conway, "Stereotypes of Femininity in a Theory of Sexual Evolution," in Suffer and Be Still: Women in the Victorian Age, ed. Martha Vicinus (1972), 153. See also, Sue V. Rossner and A. Charlotte Hogsett, "Darwin and Sexism: Victorian Causes, Contemporary Effects," and Marie Tedesco, "A Feminist Challenge to Darwinism: Antoinette L. B. Blackwell on the Relations of the Sexes in Nature and Society," both in Feminist Visions: Toward a Transformation of the Liberal Arts Curriculum, ed. Diane L. Fowlkes and Charlotte S. McClure (1984), 42-52, 53-65.

${ }^{63}$ As the focus of the Examiner on obstetrics suggests, one of the forms essentialism takes is maternity. Adam Bede suggests that realism enforces that vision of women. Bartle Massey says: "The doctor's evidence is heavy on [Hetty]-is heavy" (42.474). Within Eliot's realism, "heaviness," a conventional euphemism for pregnancy, substitutes equally for evidence; the two are almost equivalent. But Hetty's abrupt termination of her maternity, as well as the Princess Halm-Eberstein's unconventional motherhood in Daniel Deronda, suggest Eliot's complex interpretation of this supposedly essential role for women. Eliot may have complicated the question of maternity - seen it as more than simple essentialism - because for her it was a question of representation; the role of maternity touched Eliot personally as a (woman) writer. Lewes, in "The Lady Novelists," suggested that women writers might stick to topics that they could treat better than men, and Eliot echoed his thoughts: in "Woman in France," she argues that a woman writer has something to contribute because "under every imaginable social condition, she will necessarily have a class of sensations and emotions-the maternal ones-which must remain unknown to man" ("Woman in France: Madame de Sablé," in Pinney, Essays of George Eliot, 53). And yet, as a writer (who was not a mother), Eliot did not limit herself to that class of sensations. Moreover, she disparaged silly lady novelists by comparing their literary outpourings to a kind of maternal tic: she tells us that she regards them in "a very different tone from that of the reviewers who, with a 
One response to the phallocentrism built into realism is to exploit it-to compete with men on their own terms, to attempt to seize control of the structures of power by imitating them through the explicit visual metaphors of realism. One tendency within Eliot's work to accept the ruling order accounts for why feminist critics are sometimes angry at her. ${ }^{64}$ But I would like to consider now, by turning from Adam Bede to Middlemarch, the way Eliot shows that we are all, whether or not we like it, part of that order. Her fiction stresses that to embrace explicitly the constraints of a method does not make them less constraining. Obedience to that order only gives the illusion of power, one that is, in Eliot's own derogatory sense of the term, a romantic illusion, the danger and ultimate emptiness of which she dramatizes in Maggie's unsuccessful adherence to Thomas à Kempis's lessons of submission and obedience. Yet romance offers no escape either; neither of the representative possibilities open to women transforms the problems of representation.

In Middlemarch, Eliot exposes how the ability to control and regulate the category of woman becomes the tactic by which the male order (unsuccessfully) hopes to shore itself up as an order and identify itself with the system of power entrapping us all. ${ }^{65}$ If Eliot cannot write her way out of that trap, out of the constraints of representation, by highlighting the consolations of gender that privilege one group over another, she at least makes those consolations more difficult to come by.

\section{III}

Lydgate's story exemplifies how the specular defeats those who hope to gain from it. Lydgate, the scientist and doctor, is one of the

perennial recurrence of precisely similar emotions, only paralleled, we imagine, in the experience of monthly nurses, tell one lady novelist after another that they 'hail' her productions 'with delight'" ("Silly Novels by Lady Novelists," in Pinney, Essays of George Eliot, 322).

${ }^{64}$ For a different reading, and one with which I disagree, see Zelda Austin, "Why Feminist Critics Are Angry with George Eliot," College English 37 (February 1976): 549-61. This debate continues in Elaine Showalter, "The Greening of Sister George," Nineteenth-Century Fiction 35 (December 1980): 292-311.

${ }^{65}$ Brian Swann writes that, in Middlemarch, "George Eliot's perfect reader will force himself, like Dorothea after her interview with Ladislaw, "to dwell on every detail and its possible meaning' " ("Middlemarch: Realism and Symbolic Form," ELH 39 [June 1972]: 305). 
group Eliot calls "observers and theorizers" (MM.15.176), and the character in Middlemarch who trades most on observation. Eliot's metaphors of vision do not just assume but throughout the book refer insistently to the scientific method, its supposed objectivity, its transformation of empirical data into truth. Modeling himself on that "great seer" (15.177) Bichat (one of the scientists Foucault also discusses when elaborating the workings of the clinical gaze ${ }^{66}$ ), Lydgate's research quite literally relies on "careful observation" and "the use of the lens" (15.176). As his use of the microscope, that crucial image in Eliot's fiction, suggests, in his pursuit of scientific truth Lydgate holds up the smallest detail for scrutiny according to "the philosophy of medical evidence" (13.153). He believes, and Eliot seems to suggest, that such an emphasis, rather than resulting in the anarchy of Lewes's detailism, shores up the dominant order. The primitive tissue that Lydgate seeks is, as Middlemarch makes plain, another figure for the web that weaves together the novel and stands for the patterns of relations in which its characters are trapped. Lydgate hopes that his minute observations will chart

subtle actions inaccessible by any sort of lens, but tracked in that outer darkness through long pathways of necessary sequence by the inward light which is the last refinement of Energy, capable of bathing even the ethereal atoms in its ideally illuminated space. . . . He wanted to pierce the obscurity of those minute processes which prepare human misery and joy, those invisible thoroughfares which are the first lurking-places of anguish, mania, and crime. (16.194)

Critics have noted that, in this passage, Lydgate's desire to expose what is to others hidden, ignored, or inaccessible echoes directly the novel's own definition of its representations (an emphasis on vision picked up in the other familiar self-referential moments of the book: the "optical selection" governing the pier-glass and candle [27.297], the "keen vision" against which people keep themselves "well wadded with stupidity" [20.226]). Eliot's description of Lydgate's method may not be directly essentializing-she may not really be implying that the origins of human misery and joy are

66Michel Foucault, The Birth of the Clinic: An Archeology of Medical Perception, trans. A. M. Sheridan Smith (1973), 124-48; 149-73. 
biological-but, nevertheless, she implies that the microscope is an optic that wants to discover and control them: the mode it represents is identified with the desire for such knowledge and power.

When Rosamond thinks Lydgate's "preoccupation with scientific subjects . . . a morbid vampire's taste" (64.711), then, the reader cannot dismiss her entirely. The specular economy is just that: an economy in which power is gained by draining it from others-or, as several epigraphs in the novel suggest, "power is relative" (64.697), and "finds its place in lack of power" (34.357). That Lydgate's scientific speculations rest on gaining power over others is suggested by more than that he tortures frogs and rabbits in his research (15.180). Lydgate himself figures his own allegiance to scientific observation in terms of discipline and obedience. The reader is told that "fever had obscure conditions, and gave him that delightful labour of the imagination which is not mere arbitrariness, but the exercise of disciplined power-combining and constructing with the clearest eye for probabilities and the fullest obedience to knowledge" (16.193). His own obedience to a supposed ideal, Lydgate thinks, allows him to exercise its power, to raise him above the others around him; he assumes, without much consideration, that his mastery of the microscope will keep him from being in thrall to everyday details, that "the peculiar bias of medical ability . . . toward material means" (13.154) will keep the material, in the shape of jeweler's or butcher's bills, from having much effect on him. Even if Lydgate does not consciously expect to master his neighbors through his disinterested observations of truth and of them, he assumes at least that such "[noodles] could have no power over him" (15.179). The whole trajectory of Lydgate's plot, of course, is to catapult him out of such delusions. But in uncovering Lydgate's delusions, the novel repeats them. It blames him because he isn't disinterested-his spots of commonness (15.178-79), blotting his vision, are, like Hetty's or Casaubon's (42.456), the result of selfinterested egoism - and thereby still maintains the ideal of disinterested observation. This ideal is manifested, perhaps, by the novel itself, with its narrator as nobody, as general consciousness, with no self to taint it with egoism. ${ }^{67}$ Lydgate's failure attests to the novel's

67For the narrator as nobody, see Ermarth, Realism and Consensus in the English Novel, 65-92; for "the narrator as general consciousness," see J. Hillis Miller, The Form of Victorian Fiction: Thackeray, Dickens, Trollope, George Eliot, Meredith, and Hardy (1968), 53-90. 
success; his lack of power to pierce obscurity perhaps is meant to expose its own power, for, as the novel claims in Adam Bede, unlike Lydgate's, its "imagination is a licensed trespasser" $(A B .6 .115)$.

The observer draining power from that which it observes becomes particularly a question of gender. Lydgate's peculiar power as a doctor might be described as "penetration" (MM.16.186), and is one that he thinks deserves female appreciation; he expects the ideal wife, mastered by it, to worship it as sublime (58.632). The scientific method is itself figured in gender terms; adopting one of the traditional metaphors of empiricism, Eliot refers (in one of the epigraphs she wrote herself) to Nature-the Nature Lydgate hopes to penetrate-as a seductive woman (15.170). The practical observations resulting from Lydgate's scientific speculations also revolve around gender. As a doctor, Lydgate prefers to treat the Elizabeths (15.174) partly because they seem easier to control. His "strictly scientific view of women" (15.183) sees them as docile bodies, and it is that which attracts him to Rosamond:

Certainly, if falling in love had been at all in question, it would have been quite safe with a creature like this Miss Vincy, who had just the kind of intelligence one would desire in a woman-polished, refined, docile, lending itself to finish in all the delicacies of life, and enshrined in a body which expressed this with a force of demonstration that excluded the need for other evidence. (16.193)

The scientist's penetration of the obscurity of Nature hopes to attest to masculine superiority, or at least, for Lydgate, to his own particular superiority, figured in his gender.

Yet the ironic tone of the passage I have just quoted suggests that claims to superiority through the evidence of gender are also exposed and undercut in Middlemarch; the interplay of realism and romance is crucial in this critique of the consolation of gender. The power struggle that revolves around gender-especially the battle of wills between Lydgate and Rosamond-calls the authority of "the everyday details" of realism into question: with the triumph of Rosamond seems to come the triumph of romance, since she is insistently associated with the "airy conditions" of romance throughout the book (64.711). Lydgate's view of Rosamond's docility is all wrong; with a power Will Ladislaw also later comes to dread (82.861), Rosamond overmasters her lord and master. But 
the clash between Lydgate and Rosamond may be not so much a battle between modes, ending with one of them triumphant, as a means to (dead)lock those modes together and question their distinctness. Lydgate and Rosamond are much alike, as are the fictional options they represent; the metaphors representing those options keep slipping into each other. Despite Lydgate's supposedly disinterested optic, he is still blind about Rosamond; he sees in her only the reflection of his desires. Rosamond, on the other hand, is not simply a vague dreamer: the "basis for her structure had the usual airy slightness, [but] was of remarkably detailed and realistic imagination when the foundation had been once presupposed" (12.146). Lydgate's illusions about their relationship are "a mere negative, a shadow," compared to that relation seen and shaped "through [Rosamond's] watchful blue eyes" (27.305).

The interconnectedness of these figures may suggest the infiltrations of a system of relations so intimately binding that any shift in the distributions of power is only local and temporary. The power that men and women take from each other is an empty consolation, in service of an economy that benefits-by perpetuating-only itself. The horror of Rosamond's and Lydgate's story, and the great waste of their lives, is that they remain trapped together, in that bond of human relations the book symbolizes by marriage, neither ever free from or in control of the other. This waste is made to seem their fault rather than the fault of the system-made particularly to seem Rosamond's fault, so that, although she lives on after him, the moral triumph is actually Lydgate's, of course. Their story enacts the narrative's claim that "in these acts called trivialities . . . the seeds of joy are for ever wasted, until men and women look round . . . at the devastation their own waste has made" (42.462). Rosamond, in particular, is made to waste these almost seminal "seeds of joy" - the book implies that, in a sense, she destroys her (first) child, just as Hetty does. This recourse to yet another charge of infanticide, rather than indicting the sex in general, begins to recall a pattern I noted in an earlier chapter in East Lynne. The novel attempts to blame its victims, women, making into the cause of social ills what are really its effects. In its picture of the social workings of Middlemarch, this novel's blame begins to seem strained because part of what it shows is how hard it is to locate blame. 
The whole web of social interdependence catches together even the most unlikely figures, charting similarly inescapable bonds between almost everyone. In another plot that is explicit about the battles for and the workings of power, Lydgate's destiny gets inextricably intertwined with Bulstrode's, for example. Bulstrode seems the perfect illustration of the suggestion that no one owns power; his claims to it in fact facilitate his loss of it, in Middlemarch's readiness to shrug off his yoke. Yet even this story, which seems to show that such traps exceed gender, is itself worked out around gender. Bulstrode's story, like the novel, takes a "woman's lot" for its starting point, outlining "the subtle movement... shifting the boundaries of social intercourse" (11.122-23): this story too rests on the question of woman visible or invisible, the question of the "particulars of [Will's] mother's family" (61.670) and Bulstrode's part in keeping Will's mother "out of sight" (61.665).

With Bulstrode, Eliot provides another vision of what she sketches with Lydgate. Lydgate's observations seem to reveal to him (and to us) the organic whole that connects and makes meaning, which he finds symbolized by "that agreeable after-glow of excitement when thought lapses from examination of a specific object into a suffusive sense of its connections with all the rest of our existence" (16.194), a totality that the book is meant to display and reflect. Bulstrode's story is about such connectedness too but shows the dark side of it, the "entanglements of human action" (45.481). These "various entanglements, weights, blows, clashings, motions, by which things severally go on" (31.328) reveal that people "mov[e] heavily in a dim and clogging medium" (50.535), an "embroiled medium ... . [a] troublous, fitfully-illuminated life" (MM.30.324). Bulstrode's power comes in recognizing and playing on such a dim web. As Eliot notes,

Mr. Bulstrode's power was not due simply to his being a country banker, who knew the financial secrets of most traders in the town and could touch the springs of their credit; it was fortified by a beneficence that was at once ready and severe-ready to confer obligations, and severe in watching the result. . . . [H]is private charities were both minute and abundant. He would take a great deal of pains about apprenticing Tegg the shoemaker's son, and he would watch over Tegg's churchgoing; he would defend Mrs. Strype the washerwoman against Stubb's unjust ex- 
action on the score of her drying-ground, and he would himself scrutinize a calumny against Mrs. Strype. His private minor loans were numerous, but he would inquire strictly into the circumstances both before and after. In this way a man gathers a domain in his neighbours' hope and fear as well as gratitude; and power, when once it has got into that subtle region, propagates itself, spreading out of all proportion to its external means. It was a principle with Mr. Bulstrode to gain as much power as possible. (16.184-85)

This description of Bulstrode, coming as it does in the midst of the two chapters outlining Lydgate's empiricism, suggests that watchfulness and "scrutiny," rather than being objective, can be a ploy of the worst kind of egoism, a means of enforcing one's views on others.

Bulstrode, too, despite his claims to power and control, is hopelessly entangled in the same web. In the system of surveillance that maintains power, everyone is observed, no one can escape his own "shadowy monitor" (42.464), which is all the more effective in being unlocatable, dispersed throughout the system (similarly, the shadowiness of romance, rather than providing an alternative to realism, might simply provide a foil to enforce the assumptions implicit in them both). Those selfish monitors, the Featherstones, as they sit watching outside Peter Featherstone's sick room, may be in the book precisely to embody this philosophy: "there was a general sense running in the Featherstone blood that everybody must watch everybody else, and that it would be well for everybody else to reflect that the Almighty was watching him" (32.338). The Featherstones, by literally embodying this notion (it runs in their blood), suggest that this system is not controllable by human will or intention; the narration of Peter Featherstone's death and funeral ironically underscores that the pains he takes with his own will are an extreme and ill-fated reaction against, an attempt to bully away, his own ultimate powerlessness. The desire to seem in control, which both Featherstone and Bulstrode illustrate, is also one that we, as readers of the novel, share with them. The novel is able to set itself up as an ideal observer-in the position of the Almighty, the end of the chain of observers, capping and containing them-by appealing to that desire in its readers; the narrator 
consistently asks us to join in observing characters who cannot look back (11.122; 40.442-43), so that we seem to share this position of authority and autonomy. Yet our seeming autonomy is still entrapped in and determined by the specular, encoded in the naturalness with which the novel abjures us to monitor ourselves: to "set a watch over our affections and our constancy as we can over other treasures" (57.625). In Bulstrode's case, the very activity of observing overturns his claims to power: Raffles "thrust[s] himself on [Bulstrode's] unwilling observation" (60.657). The sudden vision of Raffles, and the details of his past that Bulstrode has deliberately suppressed and overlooked, do not disrupt the specular economy from which Bulstrode has profited, but they do disrupt his claims to it.

Neil Hertz suggests that Bulstrode's decrease of power seems to figure his wife's increase, an observation that points to some of the implications of gender in this economy. ${ }^{68}$ In Bullstrode's story of reduplicating gazes, his wife seems to take the position of the (ultimate) observer. After his exposure, Bulstrode imagines confessing all his sins to his wife when she is a watcher at his deathbed (85.882). That neither Mrs. Bulstrode nor Rosamond suffer the same diminishment as their husbands, that the optic of the book, in fact, brings them into prominence while their husbands fade, does not, however, suggest the mutinous victory of romance over realism, of women over men. Mrs. Bulstrode, through her husband, is herself exposed and humiliated (74.806). No amount of Gilbertian and Gubarian reading against the grain can completely redeem Rosamond or completely turn the narrative's account of what it casts as an egoism so blamable that it ultimately kills Lydgate into a subversive story of feminist resistance. A misogynistic self-hatred that, like culture, indicts women for all our ills, remains part of Eliot's fiction, an indication of the way that it too cannot escape the very cycle it concerns itself with, no more than we, as readers or interpreters, can avoid being trapped within the structures we may wish to expose.

Dorothea's story suggests another approach to that inscription, however, one that does not attempt to deny or triumph over it. Dorothea's story is much like those stories I have been charting of 
other women; Hertz sees her, too, eclipsing a waning husband, Casaubon. ${ }^{69}$ Dorothea, is, in a sense, Rosamond redeemed, as their similar plots-despite Dorothea's supposed extraordinariness, both are ultimately propelled along the same path of love and marriage-and their sympathetic coming together at the end suggest. It is Rosamond, in fact, whose supposedly false romances (her delusions about Lydgate first and then Will) enable her to see in Dorothea's story its similarity to her own and to alert readers to the degree of romance in Eliot's novel. She correctly outlines the plot of Dorothea's story, calling Casaubon's interdiction against Will "'the most charming romance. ... Mr. Casaubon jealous, and foreseeing that there was no one else whom Mrs. Casaubon would like so to marry. . . . [O]h, I have no doubt the end will be thoroughly romantic'" (59.646). Yet the airy vagueness of Rosamond's or Hetty's romances seems somehow transformed in Dorothea. In the Prelude to Middlemarch, discussing the "mere inconsistency and formlessness" (25) of the new Theresas (the original Theresa, we recall, having fed on romances), the narrator remarks:

Some have felt that these blundering lives are due to the inconvenient indefiniteness with which the Supreme Power has fashioned the natures of women: if there were one level of feminine incompetence as strict as the ability to count three and no more, the social lot of women might be treated with scientific certitude. Meanwhile the indefiniteness remains, and the limits of variation are really much wider than any one would imagine from the sameness of women's coiffure and the favourite love-stories in prose and verse. (25-26)

Women's indefiniteness, originally the narrator's tongue-in-cheek borrowing from "some"-body else, from whom it distinguishes itself-presumably, the colon implies, the same fatuous somebody who would be relieved to fix a certain limit on, that is, to define, this indefiniteness-becomes by the end of the passage the narrator's own term and woman's very way to elude limits, especially those of "scientific certitude." Moreover, this indefiniteness aligns women with and characterizes a romance that is more than simply "the favourite love-stories." Dorothea's "Quixotic" character (76.820; see 
also 2.38) lies in her ability to elude the tyranny of speculation; no one ever quite knows what she will do, and this indefiniteness is reflected at the end of the novel by the emphasis of the story on the effectiveness of her "hidden life" (Finale.896). Her vagueness seems exactly what defeats male scrutiny; in posing her as a scientific puzzle, Mr. Brooke admits his inability to solve it: "in short, woman was a problem which, since Mr. Brooke's mind felt blank before it, could be hardly less complicated than the revolutions of an irregular solid" (4.65).

But is such indefiniteness any more helpful to Dorothea than it is to that "planless riddle" (MF.6.4.505), Maggie? Unlike Maggie, Dorothea does not die at the end of her story, and her indefiniteness throughout does seem, in fact, to be a way to elude attempts to define her that are violent or dangerous. Will (whose name connects him to those will makers Casaubon and Featherstone, so concerned with maintaining their own power even after death), on one level presents the most definite threat to Dorothea. Throughout, this artist manqué is "hungry" for a "vision" of Dorothea (MM.82.860), and he vows that "he would never lose sight of her: he would watch over her-if he gave up everything else in life he would watch over her, and she should know that she had one slave in the world" (37.396). Such a relation more explicitly enslaves Dorothea than it does Will, and Mr. Hawley's warning about him- "He'll begin with flourish about the Rights of Man and end with murdering a wench" (37.393) — suggests the danger of this slavery for Dorothea. Will's supposed enslavement to her ("I would rather touch her hand if it were dead, than I would touch any other woman's living" [78.836]) is chilling in its imagery and, through its language, again ties him to his relation, Casaubon, whose own dead hand attempts to control Dorothea (and suggests the way the male order attempts to circumvent its own vulnerabilities by projecting them onto women). Will's vision of Dorothea in the Hall of Statues acts out the reifying tendency of his impulses and places it within the novel's larger concern with the real; this careful observation of Dorothea is little different from the reader's, from the first pages of the novel, where the reader is asked to attend to the details of the picture of Miss Brooke, to focus on her "hand and wrist" (1.29), just as Naumann and Will later gaze at her. 
Does Dorothea's hidden life at the end of the novel, then, present another perspective, a valid romance, somehow better than Hetty's or Rosamond's dreams? Eliot makes Dorothea obscure at the end of the novel (obscure both in her social world-she slips from gentility into the mass-and for Eliot's readers-we no longer minutely observe her) in a way that does not really seem to unsettle any limits; in fact, her effacement in aiding Will's career in government could be seen as the ultimate service to patriarchy.

Moreover, like Maggie (or Hetty, or Rosamond), Dorothea is not solely identified with the obscure or unrepresentable. As Virginia Woolf has written, the tragedy of all these women may be that they demand something "perhaps incompatible with the facts of human existence."70 They are nonetheless firmly enmired in those facts. In the schoolroom-where, Mary Jacobus suggests, both characters and readers are being taught about women-Maggie is aligned with the particular: she brings on Mr. Stelling's observations about her sex in general by skipping the rules of Latin because the examples are so absorbing $(M F .2 .1 .217) \cdot{ }^{71}$ For Dorothea, an attention to detail is exploded early by the novel, shown to be the very mechanism that delivers her over into patriarchy. Her misguided romance about Casaubon before their marriage sees that patriarch as a savior, one who will especially save her from the world of the everyday. Because Casaubon seems to her "unconscious that trivialities existed" (MM.3.55), she feels certain that their lives together will elude banality; she says that "'there would be nothing trivial about our lives. Everyday-things with us would mean the greatest things'" (3.51). Instead, Dorothea's marriage makes her aware that she is inescapably part of the everyday: "that new real future which was replacing the imaginary drew its material from the endless minutiae by which her view of Mr. Casaubon and her wifely relation, now that she was married to him, was gradually changing

70Virginia Woolf, "George Eliot," in Women and Writing, ed. Michèle Barrett (1979), 159.

71Jacobus, Reading Woman, 69. Maggie, through her association with detail, joins a family of similar women in Eliot's early books: the sharp-eyed Mrs. Poyser, or her own mother, Mrs. Tulliver, whose household "objects" make life "comprehensible" to her (MF.4.2.368). Even Dinah, who, at the start of Adam Bede "seemed unobservant of all details" (AB.15.205), has, through her love for Adam, so changed by the end of the book that he can remark approvingly, "You're getting to be your aunt's own niece, I see, for particularness" (AB.50.536). 
with the secret motion of a watch-hand from what it had been in her maiden dream" (20.226). Rather than a life of transcendence, Dorothea finds herself forced to dwell within the endless minutiae of a reality that dispels her dreams.

Mutual surveillance is what binds Dorothea with Will; both long for the sight of the other. Although he is wrong to ascribe to Dorothea lack of sympathy and individual malevolence, Casaubon is not far wrong when he suspects her as a "spy watching everything with a malign power of inference" (20.232-33). The book suggests that even the best of us are defined by and vehicles for an impersonal field of control. For all of Dorothea's short-sightedness and abstraction (" 'Dodo, how very bright your eyes are!' " Celia at one point exclaims, "'And you don't see anything you look at'" [77.833]), for all her disclaimers about being unable to understand paintings $(9.105 ; 21.238 ; 62.678)$, the implication throughout the book is that she does see, although perhaps in a way different from the others. Celia consistently disparages "the strange coloured lamps by which Dodo habitually saw" (84.878); she tells her that "'you always see what nobody else sees . . . you never see what is quite plain'" (4.59). Yet Dorothea's vision, like vision throughout the novel, still causes other pain: her "way of looking at things" is like "spilt needles, making one afraid of treading, or sitting down, or even eating" (2.43).

When Will first meets Dorothea, he recognizes her as "one of Nature's inconsistencies" (9.105), and, as Eliot tells us in an epigraph from Rasselas, "Inconsistencies . . . cannot both be right, but imputed to man they may both be true" (61.660). Unlike Dr. Johnson, Eliot imputes them to women. For Lydgate, what is most damning about Dorothea's view (and perhaps about her having a view at all) is that it is not from "the proper feminine angle" (11.122). Dorothea's characterization engages our feminist sympathies precisely because her vision seems to refuse what has been decreed as proper to it. Yet what may be ultimately most attractive about Dorothea is not that she is an impossible rebel but that she is so ordinary, torn between the desire to be different from her world and her recognition of the impossibility of being so. Dorothea may be distinctive in this novel because she accepts her ordinariness. Her view is different from others because, as another Eliot epigraph suggests, "[she] seeth only that [she] cannot see" (20.224). 
The novel may emphasize that famous climax of Dorothea at the window (in chapter 80) not for its reclaimed faith in what is actually the empty consolation of human activity but because it accepts that that activity is inescapably embroiled in a system outside our control. Through Dorothea, the book suggests that none of us, least of all women, is outside the gaze, nor can we control it:

She opened her curtains, and looked out towards the bit of road that lay in view, with fields beyond, outside the entrance-gates. On the road there was a man with a bundle on his back and a woman carrying her baby; in the field she could see figures moving-perhaps the shepherd with his dog. Far off in the bending sky was the pearly light; she felt the largeness of the world and the manifold wakings of men to labour and endurance. She was part of that involuntary, palpitating life, and could neither look out on it from her luxurious shelter as a mere spectator, nor hide her eyes in selfish complaining. (80.846)

The emphasis on labor and endurance, the inevitability, the involuntariness of our position as subjects within both sides of the specular, our unchangeable position in a double bind-this is all the resolution of Eliot's novel. And the bind comes partially because our very exposure of the system simply continues the mechanism that constructs and furthers it in the first place. Farebrother's suggestion that "the stronger thing is not to give up power, but to use it well" (52.554) may be the closest the book comes to a solution, but it is one still trapped in the logic it questions, within a tautology where, in questions of power, the good must be the strong.

Eliot's fiction suggests that women are also part of the power system that constrains them. To see women implicated in that inequitable system within which they suffer, too, bespeaks the same kind of ambivalence or deadlock that we have been discussing between realism and romance-and perhaps resolves itself into the same ultimate deployment of and subordination to that system. Although feminists often gesture to Eliot's unconventional life as evidence of her true insubordination, there are daunting indications enough of capitulation in Eliot's private writings, as well as in her novels; Eliot seems ready enough to blame women 
for the ills of the world in which she operates while according the power of that world to men. She tells one female correspondent that "woman does not yet deserve a much better lot than man gives her," and similar statements run throughout her letters, all resulting from what she tells another female friend: that, for Eliot, men somehow "always eclipse the female-pardon the word."72

Yet "eclipse" (if that is the word we are to pardon), by pointing to Eliot's dissection of the specular, also allows us to pardon this attitude in Eliot (or, rather, to see that we are in no position to pardon her), to see that attitude as what even that literary patriarch, Leslie Stephen, recognized as "bitterness . . . a kind of misgiving" - one that colored Eliot's view of women. ${ }^{73}$ This jeu de melancolie (what Eliot called The Lifted Veil) comes from the recognition that everyone is enmired in a system that lays everything to waste, whether we ignore or dwell on that sight. ${ }^{74}$ This is the horrid picture of The Lifted Veil, what Latimer comes to learn, for when the veneer of life is "seen as if thrust asunder by a microscopic vision, [it] showed all the intermediate frivolities, all the suppressed egoism, all the struggling chaos of puerilities, meanness, vague capricious memories, and indolent make-shift thoughts, from which human words and deeds emerge like leaflets covering a fermenting heap." 75 That the inescapable structure of sight reveals this fermenting heap as the only available site-the site on which those of us hoping for better must found a sympathetic construction of woman and of the social change that might benefit her-explains Eliot's bitterness. Like Gwendolen Harleth, Eliot may feel "a sort of terror: it was as if some ghastly vision had come to her in a dream and said, 'I am a woman's life'" (DD.14.190). To keep from denying this vision, as

72The first reference is "George Eliot to Mrs. Peter Alfred Taylor, London, 1 February 1853," in Letters, 2: 86; the second, "George Eliot to Sara Sophia Hennell, [London, 25 June 1852]," in Letters, 2:38.

73"Unsigned Obituary Article," from Stephen's journal Cornhill, in Carroll, George Eliot: The Critical Heritage, 483. Stephen goes on to write: "We must admit that there is something rather depressing in the thought of these anonymous Dorotheas feeling about vaguely for some worthy outlet of their energies . . . wishing ardently to reform the world, but quite unable to specify the steps to be taken, and condescending to put up with a very commonplace life in a vague hope that somehow or other they will do some good" (Carroll, George Eliot: The Critical Heritage, 483).

74"George Eliot to John Blackwood, [Wandsworth] 31 March [1859]," in Letters, 3: 41.

${ }^{75}$ George Eliot, The Lifted Veil (1985), 19-20. 
Gwendolen does, Eliot may embrace it with a vengeance that turns on women-herself included.

Although Eliot cannot imagine a way of salvaging this waste, she holds open the possibility that her sifting through it may ultimately provide a clue; she conjectures that a piece of debris, unremarked by us now "may end by letting us into the secret of usurpations" (MM.41.448). Her writing becomes a kind of stop-gap, whose ultimate effectiveness lies not with Eliot but, perhaps, with some future reader: "a bit of ink and paper which has long been an innocent wrapping or stop-gap may at last be laid open under the one pair of eyes which have knowledge enough to turn it into the opening of a catastrophe" (MM.41.448). Eliot's writing becomes what she later says about the laws to help women, of which she earlier seemed skeptical: "one round of a long ladder stretching far beyond our lives."76 To gesture provisionally to some possible change, despite the present impossibility of such changes-despite her recognition of the inevitable self-defeat of such gestures-seems wishful in Eliot, but if we as her critics are to accuse her for it, we align ourselves with (the old) Adam in our lack of fellow-feeling, for he too cannot accept "the weakness that errs in spite of foreseen consequences" (AB.19.255).

By placing woman within the specular, then, Eliot does not completely cut the ground out from under feminism; her work instead suggests that locating claims for power solely in terms of the male (as one side of the dispute about the male gaze and feminist directions wishes to do) risks supplying feminists with our own gender consolation that allows us to ignore our own implication in dominant systems - an ignorance that impedes, if not undoes, our investigations. It bears repeating what feminism already knows well but often wishes, understandably and even of necessity, to overlook: that a critique is not (nor does it need to be) a solution; that simply to expose a strategy as male does not undo it; that our investigations must repeat on some level the very mechanism we are analyzing; and that just to recognize our implication-a currently overmystified tactic of post-structuralism-is not necessarily subversive, because our recognition does not somehow mag-

76"George Eliot to Sara Sophia Hennell, Richmond, [28 January 1856,]" in Letters, 2: 227 . 
ically free us from it. Eliot's novels show that she does not advocate, on the other hand, that we stop critiquing, exposing, investigating, and recognizing our position in the power struggles played out in gender relations-by no means - for to do so is just the flip side of the same old thing, one of those delusive opposites everyone oscillates between.

That such crucial recognitions are all our lot offers us may in fact correspond with Freud's recognition that the best he could offer his patients was an informed self-recognition that translated their misery into common unhappiness. ${ }^{77}$ What seems the pessimism of George Eliot's fiction, and the real reason that feminists are often angry at her, may reflect the concentration of her fiction on the limits of the possibilities for directly willed feminist change. But rather than being antifeminist, her fiction enables our feminist struggle by highlighting that that struggle is necessarily interminable and that it must go on despite the absence of a clear goal or reward. The much-discussed loss of faith fueling Eliot's fiction may well be another version of the way the very issue of the doubtfulness of our endeavors provides the focus that fuels and justifies them. Eliot's peculiar double vision about feminism-that her works seem caught between a clarity of vision and a willful blindness when it comes to the causes of gender inequities-exposes the contradictions within feminism rather than dispensing with it. Her novels, in attempting both to establish and to question their

77Sigmund Freud, "The Psychotherapy of Hysteria," SE, 2: 305. It is intriguing that Freud makes this suggestion especially when he is discussing problems peculiar to gender division (which, feminists might argue, come to seem women's problems), as he does in this essay, and later, when the impossibility of a cure becomes the very focus of "Analysis Terminable and Interminable" (SE, 23: 209-53). In that pessimistic essay, he suggests that gender division itself leads to the problems that cannot be cured and the unhappiness that cannot be alleviated: "At no other point in one's analytic work does one suffer more from an oppressive feeling that all one's repeated efforts have been in vain, and from a suspicion that one has been 'preaching to the winds,' than when one is trying to persuade a woman to abandon her wish for a penis on the ground of its being unrealizable or when one is seeking to convince a man that a passive attitude to men does not always signify castration and that it is indispensable in many relationships in life" ("Analysis," in SE, 23: 252). The underlying biologism of Freud's claim (he writes that, with such essential sexual differences, "we have penetrated through all psychological strata and have reached bedrock" ["Analysis," in SE, 23: 252]) suggests not only his wish to locate the source of our unhappiness but also the way he reaffirms the particular bedrock that will support his approach. 


\section{Women and Romance}

own authority, interrogate the question of gender within the metaphor of vision that underwrites them-a metaphor that they, too, do not just adopt but investigate. Their examination provides a kind of admonitory vision, which suggests the necessity of keeping the limits on us as subjects from letting us as feminists settle for a complacent pessimism, of continuing instead the necessary process of self-examination. Like Dorothea, Eliot may yearn "after order and a perfect rule" (MM.9.98); with an "eagerness for a binding theory" (10.112), she may impatiently identify herself with the very authority she cannot escape, but she nowhere settles long for it, nor for easy answers. 